\title{
The Bellelli family
}

\author{
R. W. Shillitoe
}

Edgar Degas (1834-1917) is perhaps best remembered for his pictures of women bathing and of ballet dancers. The awkward posing, the physical unattractiveness and the voyeuristic viewpoints that are characteristics of many of his later works have given him a reputation for misogyny. A lesser known aspect of Degas' work concerns portraiture. In the earlier part of his career he painted many portraits of his family and friends which are remarkable for their psychological insights as well as their technical and compositional mastery. One of the finest is the portrait of the Bellelli family which he started in Florence in 1858 and appears to have worked on intermittently until 1867. Its large size $(200 \times 250 \mathrm{~cm})$, the length of time in execution and the number of preparatory studies all point to its significance in the artist's eyes. Despite this, scholars doubt that it was ever exhibited during Degas' lifetime and was discovered with considerable surprise in his studio following his death (Boggs, 1994).

The family consists of Baron Gennaro Bellelli, his wife Laura, who was Degas' aunt (his father's sister), and their daughters, Giovanna and Giula. In a sense, Laura's father Hilaire, is also present; his is the framed portrait on the wall - a portrait within a portrait. Some commentators have suggested that Laura is pregnant. This would explain the cradle that is half-visible behind her, but there is no conclusive evidence that she was expecting.

Materially and emotionally the family was experiencing difficulties at the time when Degas

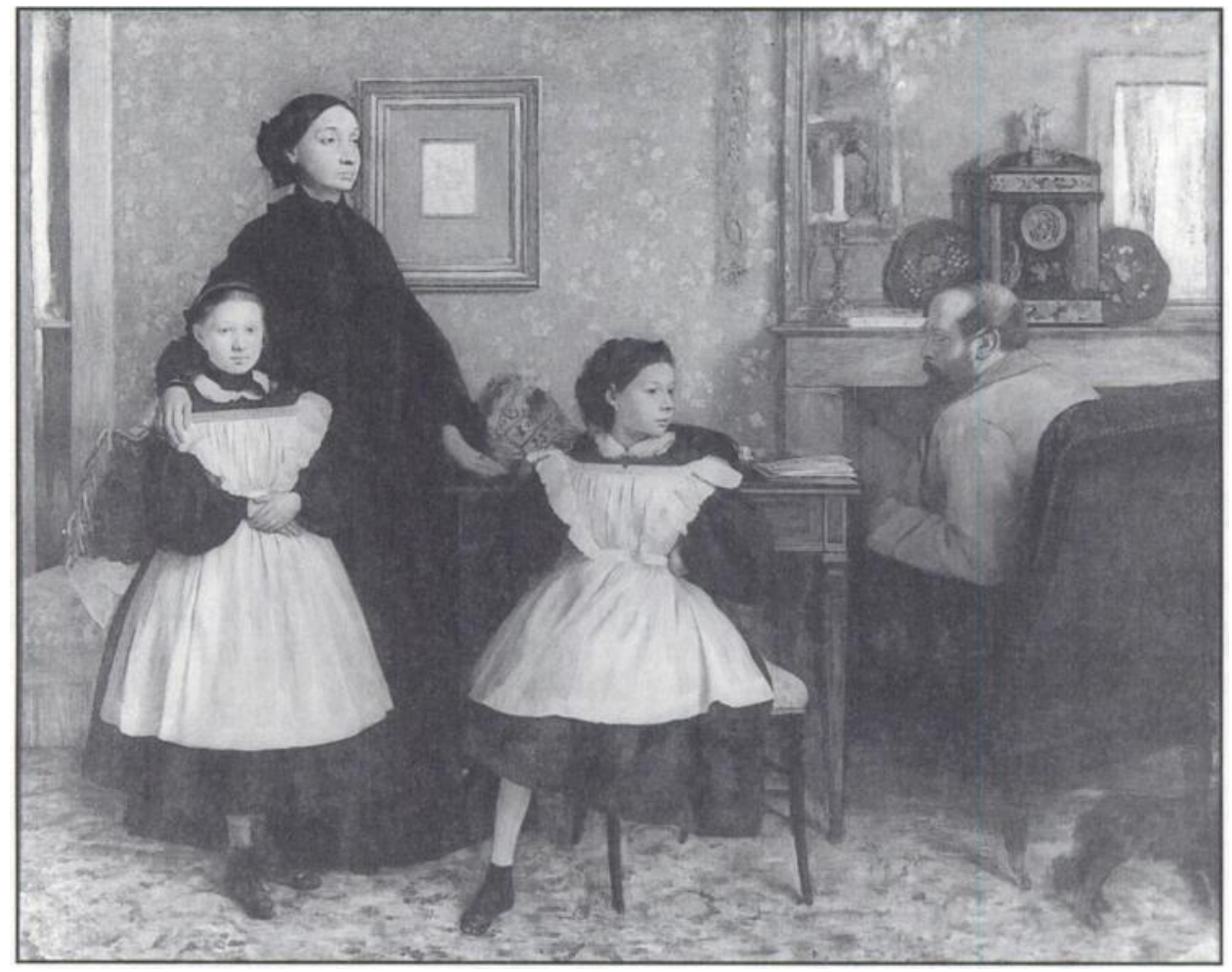

Figure 1. The Bellelli family, 1858-67, Edgar Degas, oil on canvas, Paris, Musée d'Orsay (C) Agence Photographique de la Réunion des Musées Nationaux, Paris 1998. 
began work on the painting. The Baron, a lawyer and politician, had been exiled from Naples thanks to his participation in the revolution of 1848 and the family was living in rented accommodation in Florence. Hilaire had recently died (hence Laura's black mourning dress). The marriage is known to have been unhappy. Laura was very open and frank about this. She wrote to Degas that "living with Gennaro, whose detestable nature you know and who has no serious occupation shall soon drive me into my grave" (Nochlin, 1992).

Some of this change and instability is suggested by the pose of the figures. Laura's hand rests on the table as though she is trying to steady herself. Giula, described in a letter by Degas as having "the disposition of a devil and the kindness of a little angel" (Reff, 1969), perches awkwardly and precariously on one leg on the edge of her chair. The family dog is depicted on the right, in the act of walking out of the picture, further emphasising the sense of restlessness.

This visible tension is heightened by the way in which it contrasts with the formal elements of the painting. The coolness of the colours - the blue-grey of the wallpaper, the dark fabric of the chair, the black of the dresses and the white of the girls' aprons - combine with the austerity of the hair styles to give a feeling of great restraint and self-control. This is augmented by the upright and self-contained poses of the mother and elder daughter. Giovanna clasps her hands firmly, almost literally holding herself together while her mother places a steadying hand on her shoulder.

Spatially, the mother and children form a selfcontained group, separated both psychologically and physically from the Baron who, facing away from the viewer and half-turned from his family, occupies a niche of his own bordered by the edge of the table and the back of the chair. There is a contrast, too, between the formal and erect poses of the figures of Laura and her elder daughter and the slumped posture of the Baron.

Look at the eyes. In family portraits, the people depicted generally look out of the picture space at the artist/viewer or else they look at some common point of interest. Sometimes they look at each other. Here, however, there is little interaction and no common point of interest. It is as though the family members are deliberately avoiding eye contact. The father gazes at his family, like an outsider watching them pose, but they do not return his gaze. Laura stares with head held high into the far distance. Giovanna alone establishes eye contact with the viewer while Giula looks hastily to her left, embarrassed, unable to bear being observed.

The picture plane is very flat and encourages us to read the painting from left to right, as we would read a frieze or the lines on a printed page. This analogy of 'reading' the picture is not accidental. Parisian gallery goers would have expected pictures to be readable as a narrative from the poses, the gestures and the disposition of the figures. As a family therapist might do, Degas has sculpted the family. In the arrangement of the figures we can read the patterns of interrelations between the family members. In their expressions and their gestures we can read their psychological states. The internal tensions within the Bellelli family are made very public. One wonders how the family would have responded to having the Baron's deficiencies and his family's alienation displayed to all the world. Perhaps it was some family feeling that prevented Degas from exhibiting it.

Whatever Degas' ultimate view was of women, here he is clearly on the side of his aunt and nieces. His particular skill lies in displaying the undercurrents within a setting of bourgeois orderliness. Behind the apparent tranquillity he has produced one of the finest 19th century portrayals of a dysfunctional family.

\section{References}

BogGS, J. S. (1994) Degas as a portraitist. In Degas Portraits (eds F. Baumann \& M. K. Karabelnik), pp. 17-85. London: Merrell Holberton.

Nochun, L. (1992) A house is not a home: Degas and the subversion of the family. In Dealing with Degas (eds $R$. Kendall \& G. Pollock), pp. 43-65. New York: Universe.

REFF, T. (1969) More unpublished letters of Degas. Art Bulletin, 51, 283.

R. W. Shillitoe, Consultant Clinical Psychologist, Airedale General Hospital, Steeton, West Yorkshire BD20 6TD 